\title{
Penerapan Model Kooperatif Tipe Team Games Tournament dalam Volley Ball Like Games
}

\section{Refky Sudrajat Ramadhan}

Universitas Pendidikan Indonesia, Indonesia

\section{Info Artikel \\ SejarahArtikel: \\ Diterima Juli 2019 \\ Disetujui September 2019 \\ Dipublikasikan Oktober 2019}

\section{Keywords:}

Team Games Tournament, Volley Ball Like Games

\begin{abstract}
Abstrak
Studi ini bertujuan untuk mengetahui apakah model kooperatif tipe TGT (Team Games Tournament) melalui volley ball like games dapat meningkatkan keterampilan bermain mini voli. Penelitian menggunakan metode penelitian tindakan kelas, dengan partisipan adalah siswa kelas VB SDN 178 Gegerkalong KPAD Kota Bandung, Yang berjumlah 30 siswa (16 laki-laki; 13 perempuan). Data penelitian diambil dengan menggunakan format penilaian Games Performance Assessment Instrument (GPAI). Hasil penelitian ini menunjukan adanya peningkatan, rata-rata nilai pada pre-test yang diperoleh siswa sebesar 69, dan pada siklus akhir rata-rata nilai siswa sebesar 78 . Dengan begitu dari hasil dapat disimpulkan bahwa penerapan model kooperatif tipe TGT melalui volley-like games dapat meningkatkan keterampilan bermain minivoli pada siswa kelas V SDN Gegerkalong KPAD Kota Bandung.
\end{abstract}




\section{PENDAHULUAN}

Pendidikan jasmani merupakan proses pendidikan melalui aktivitas jasmani yang dijadiakan sebagai media untuk mencapai perkembangan dan pertumbuhan secara individu. Erliana, (2014). "Pendidikan jasmani merupakan salah satu alat penting untuk merangsang pertumbuhan dan perkembangan tersebut, karena pendidikan jasmani sangat erat kaitannya dengan gerak manusia”. Dari pernyataan di atas, maka pendidikan jasmani di sekolah dasar sangat penting karena pada usia sekolah dasar perkembangan dan petumbuhan sangat di perlukan oleh siswa. Widiyanti (2013) "Usia sekolah dasar kurang lebih (7-13 tahun) merupakan masa pertumbuhan yang cepat. Apalagi usia anak kelas 4 sampe 6". Proses pembelajaran pendidikan jasmani di sekolah dasar harus disusun dengan cermat dan sesuai dengan tingkat perkembangan anak (sesuai dengan karakteristik siswa dan materi yang di ajarkan), karena jika proses pembelajaran dilaksanakan dengan keasal-asalan (yang penting anak berkeringat) yang tadinya akan membantu anak untuk bekembang dan tumbuh secara optimal menjadi menghabat siswa untuk tumbuh dan optimal.

Permainan mini voli harus di ajarkan untuk anak sekolah dasar sebab dalam pembelajaran mini voli terdapat aspek kognitif, apektif, dan psikomotor. Murtiyono \& Raharjo (2015). Dari penelitian tersebut dapat disimpulkan bahwa "permainan mini voli terdapat tiga aspek penting kognitif, afektif dan psikomotor, dan permainan mini voli dapat meningkatkan ketiga aspek hasil belajar". Selain itu dalam permainan mini voli juga terdapat gerak dasar seperti lokomotor, non-lokomotor dan manipulatif, dengan begitu siswa akan mendapatkan pengalaman gerak yang banyak. Suherman A. (2009) "Pendidikan Jasmani merupakan bagian dari program pendidikan secara umum yang terutama melalui pengalaman-pengalaman gerkannya memberi sumbangan terhadap pertumbuhan dan perkembangan anak secara menyeluruh" dengan begitu dari pemaaparan di atas dapat di simpulkan bahwa permainan mini voli cocok diterapkan di sekolah dasar.
Pembelajaran mini voli sudah banyak diterapkan menjadi materi pokok selain pembelaran futsal. Akan tetapi pembelajaran mini voli di sekolah dasar yang peneliti lihat pembelajarannya kurang menarik karena banyak siswa yang tidak berperan aktif dalam pembelajaran, dengan begitu pembelajaran hanya di ikuti oleh siswa yang sudah di katakana bisa saja. Hal itu disebabkan oleh penerapan model konvesial atau pembelajaran berpusat pada guru (TeacherCentered). Karim, dkk (2017) "Pembelajaran yang diberikan oleh guru dianggap kurang efektif, karena guru memegang penuh peranan pembelarajaran. Sehingga siswa hanya bisa mengikuti apa yang di perintah guru, akhirnya siswa kurang mendapatkan hasil yang optimal". Pembelajaran yang seperti itu sering munculnya emosional siswa yaitu rasa bosan dan disertai dengan ketidakseriusan untuk melakukan kegiatan pembelajaran sehingga pembelajaran tidak berlangsung optimal. Selain itu yang peneliti lihat di lapangan penggunaan media pembelajaran yang kurang sesuai dengan usia siswa sekolah dasar, yang mengakibatkan banyak siswa yang kesulitan memainkan atau mempertahankan bola di udara dikarenakan media yang di gunakan dalam pembelajaran adalah media.

Maka dari itu, peneliti akan memberikan materi ajar mengenai pembelajaran mini voli melalui pembelajaran volley ball like games. Bola voli baru layak diajarkan pada kepada anak usia 12/13 tahun. Hal ini di karenakan peralatan serta gerakannya cenderung akan destruktif dibandingkan konstruktif ketika di ajarkan pada siswa SD (Marwati, 2009). Untuk itu perlu adanya sebuah modifikasi sehingga permainan ini dapat tersampaikan di SD.

Di sini peneliti memilih model pembelajaran kooperatif tipe TGT (Team Games Tournament). Dalam model pembelajaran kooperatif tipe TGT siswa harus berperan aktif dalam pembelajaran, Karena dalam model pembelajaran kooperatif siswa tidak belajar dari guru saja akan tetapi siswa bisa belajar dari temannya dan siswa yang sudah bisa akan mengajarkan temanya jika ada temanya yang kesulitan tentang materi pembelajaran. Pembelajaran 
kooperatif tipe TGT lebih menekankan interaksi antar siswa. Dari sini siswa akan melakukan komunikasi aktif dengan temannya. Dengan komunikasi tersebut diharapkan siswa dapat menguasai materi pelajaran dengan mudah karena siswa lebih mudah memahami penjelasan dari kawannya dibanding penjelasan dari guru karena taraf pengetahuan serta pemikiran mereka lebih sejalan dan sepadan. (Hasanah \& Rahman, 2017).

Selain itu dalam model pembelajaran kooperatif tipe TGT (Team Games Tournament) dapat memotivasi siswa supaya dirinya bisa melalukan keterampilan bermain yang ada dalam materi tersebut sebab dalam model ini pembelajaran akan di akhiri dengan adanya sebuah tournament dan pemenanngnya akan di berikan pengahrgaan. Nugroho, W. (2012) “Dengan menggunakan model ini, siswa dapat lebih aktif dengan saling membantu antar teman untuk memahami materi, saling memberi motivasi atau dorongan dan evaluasi”. Dalam penelitian ini tidak hanya menggunakan model pembelajaran, akan tetapi modifikasi pembelajaran juga, karena dengan memodifikasi pembelajaran guru penjas akan memperhatikan kemampuan peserta didik dan proses pada pada saat pembelajaran. R. Pudjilah M. (2017) "Modifikasi sangat tepat dilakukan, karena selain variasi mengajarnya bayak, penyesuaian terhadap kemampuan anak sehinngga mereka tidaklah terlalu bosen mengikuti pembelajaran, termotivasi dam bergairah untuk bergerak".

Penelitian ini memodifikasi permainan mini voli menjadi volley ball like games, sebab volley ball like games ini menggunakan media dan peraturan yang di sesuaikan dengan usia peserta didik. Bahagia \& Mujianto (2017) "Volley ball like games adalah permainan yang menyerupai voli, sehingga dilakukan modifikasi diberbagai aktivitas atau alat serta lapangan dan aturan yang digunakan sehingga permainan ini dilakukan berbagai level keterampilan siswa".

\section{METODE}

Jenis penelitian yang peneliti gunakan dalam penelitian ini adalah penelitian tindakan kelas (classroom action research) yang mengacu pada model penelitian tindakan dari Kemmis \& MC Taggart (dalam Arikunto, 2013). Penelitian ini dilakukan dengan 2 siklus dan setiap siklusnya terdiri dari 2 tindakan. Sehingga semuaya berjumlah 4 pertemuan, satu tindakan merupakan satu pertemuan.

Populasinya merupakan siswa kelas VB di salah satu sekolah dasar di Kota Bandung, yang terdri dari 30 siswa, 13 siswa laki-laki dan 16 siswa perempuan. Instrumen dalam penelitian ini menggunakan lembar observasi, catatan lapangan, dan rekaman foto. Lembar observasi menggunakan format GPAI (Games Performance Assesment Instrument) Oslin, dkk (1998; Memmert, D, \& Harvey, S. (2008). Data disajikan dalam bentuk persentase.

\section{HASIL DAN PEMBAHASAN}

Penelitian dilakukan untuk mengetahui bagaimana hasil dari setiap tindakan yang dilakukan apakah keterampilan bermain mini voli meningkat atau tidak. Dari hasil observasi awal yang telah diteliti oleh peneliti tersaji di dalam Gambar 1.

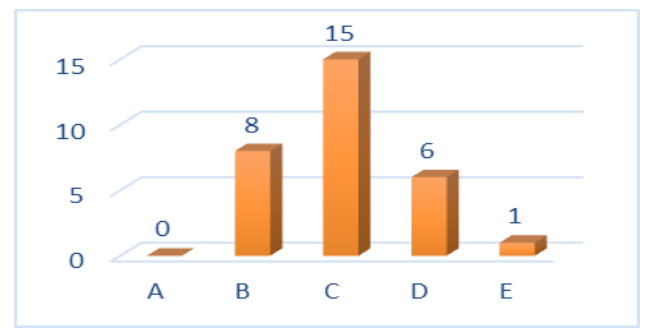

Gambar 1.

Hasil Observasi Awal Keterampilan Bermain

Berdasarkan hasil observasi awal pada Gambar 1, dapat dilihat bahwa kemampuan siswa mengenai keterampilan bermain mini voli dalam volley ball like games masih sangat rendah, siswa yang mendapatkan nilai $\mathrm{A}=0(0 \%), \mathrm{B}=8(26,67 \%), \mathrm{C}=15$ $(50,00 \%), D=6(20,00 \%)$, dan $E=1(3,33 \%)$. Nilai rata-rata yang didapatkan adalah $68,88 \%$. 


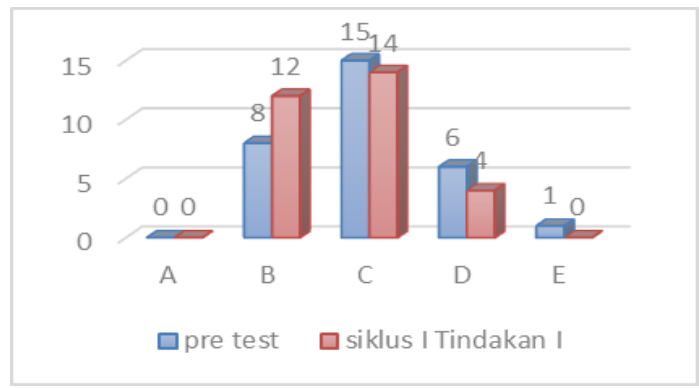

Gambar 2

Hasil Siklus 1 Tindakan 1 Keterampilan Bermain

Berdasarkan hasil siklus 1 tindakan 1 pada diagram 2, peneliti menemukan bahwa kemampuan siswa mengenai keterampilan bermain mini voli dalam volley ball like games masih rendah, siswa yang mendapatkan nilai $\mathrm{A}=0(0 \%), \mathrm{B}=12(40,00 \%)$, $\mathrm{C}=14(47,00 \%), \mathrm{D}=4$ (13,00\%), dan $\mathrm{E}=0$ (0\%). Nilai rata-rata yang didapatkan adalah $70,78 \%$.

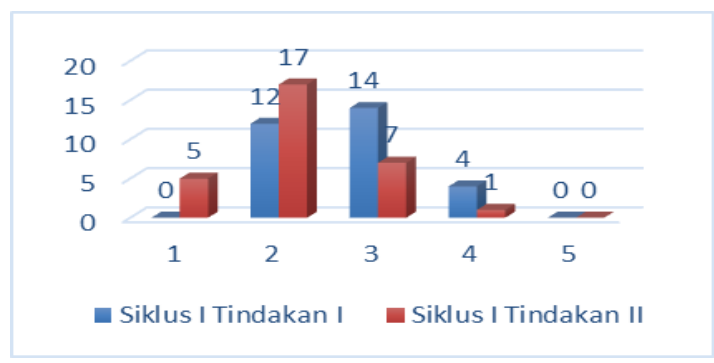

Gambar 3

Hasil Siklus 1 Tindakan 2 Keterampilan Bermain Mini voli

Hasil siklus 1 tindakan 2 pada Gambar 3, peneliti menemukan bahwa kemampuan siswa mengenai keterampilan bermain dalam volley ball like games masih rendah, tetapi banyak siswa yang belum meningkat, siswa yang mendapatkan nilai $\mathrm{A}$ $=5$ (16,67\%), $\mathrm{B}=17$ (56,67\%), $\mathrm{C}=7$ (23,33\%), $\mathrm{D}=1 \quad(3,33 \%), \quad$ dan $\quad \mathrm{E}=\quad 0 \quad(0 \%)$.

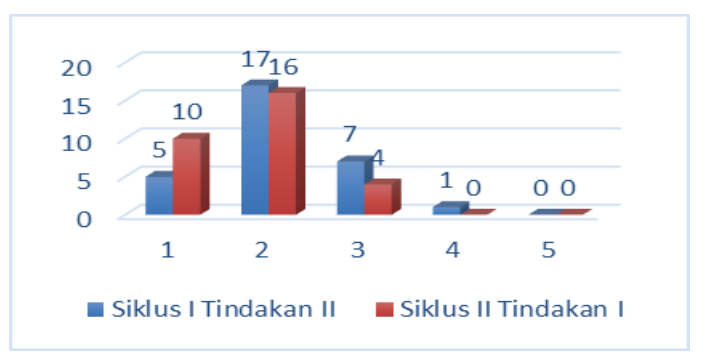

Gambar 4

Hasil Siklus 2 Tindakan 1 Keterampilan Bermain
Berdasarkan hasil siklus 2 tindakan 1 pada Gambar 3, peneliti menemukan bahwa kemampuan siswa mengenai keterampilan bermain dalam volley ball like games sudah mulai ada peningkatan, siswa yang mendapatkan nilai $\mathrm{A}=10 \quad(33,33 \%), \mathrm{B}=16$ $(53,33 \%), C=4(13,33 \%), D=(0 \%)$, dan $E=0(0 \%)$. Nilai rata-rata yang didapatkan adalah $75,98 \%$.

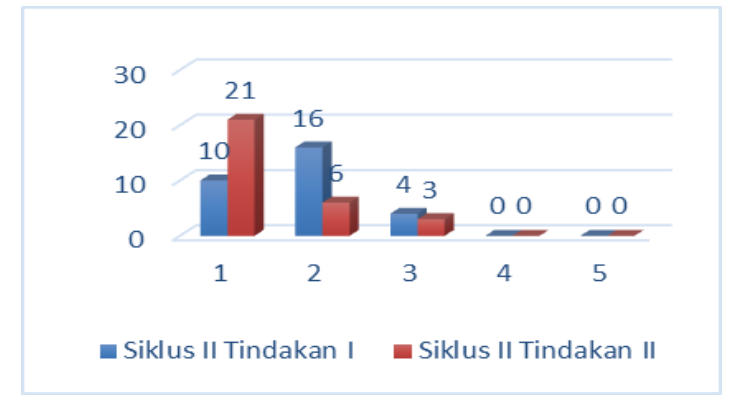

Gambar 4

Hasil Siklus 2 Tindakan 2 Keteampilan Bermain

Berdasarkan hasil siklus 2 tindakan 2 pada Gambar 4, peneliti menemukan bahwa kemampuan siswa mengenai keterampilan bermain mini voli dalam volley ball like games meningkat, siswa yang mendapatkan nilai $\mathrm{A}=21(70,00 \%), \mathrm{B}=6 \quad(20,00 \%)$, $\mathrm{C}=3(10,00 \%), \mathrm{D}=0(0 \%)$, dan $\mathrm{E}=0(0 \%)$. Nilai ratarata yang didapatkan adalah 83,33\%. Hasil keseluruhan keterampilan bermainn terdapat pada gambar 5 .

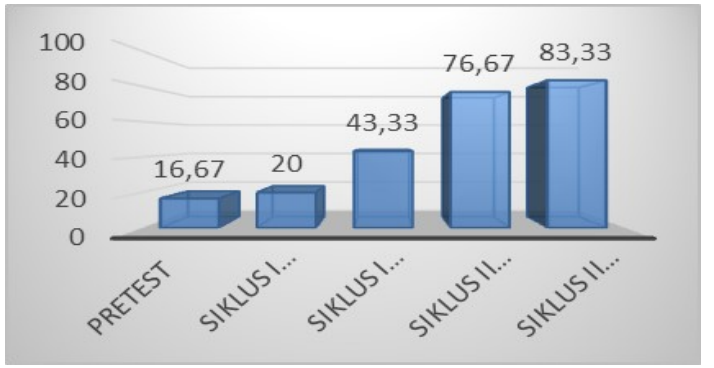

Gambar 5

Hasil Akhir Keterampilan Bermain

Berdasarkan hasil akhir penelitian pada Gambar 5, peneliti menemukan bahwa kemampuan siswa dalam melaksanakan atau menguasai keterampilan bermain mengalami peningkatan presentase setiap 
siklus dan tindakannya, pada pre-test presentase keseluruhan siswa sebesar (16,67\%), pada siklus 1 tindakan 1 presentase keseluruhan siswa $(20,00 \%)$, lalu pada siklus 1 tindakan 2 presentase keseluruhan siswa $(43,33 \%)$, kemudian siklus 2 tindakan 1 presentase keseluruhan siswa $(76,67 \%)$, pada akhir siklus 2 tindakan 2 presentase keseluruhan siswa $(83,33 \%)$. Dengan demikian proses pembelajaran volley ball like games menggunakan model kooperatif yang diberikan dapat tercapai sesuai dengan tujuan pembelajaran yang diharapkan atau sesuai nilai ketuntatas.

Pada pemaparan pembahasan hasil penelitian di atas, dapat disimpulkan bahwa dengan penerapan model Kooperatif tipe TGT (Team Games Tournamnet) dapat meningkatkan keterampilan bermain mini voli. Karena dengan penerapan model pembelajaran kooperatif membuat siswa lebih berperan aktif dalam mengikuti pembeljaran dan motivasi siswa untuk mengikuti pembelajaran lebih baik, dengan begitu pembelajaran tidak hanya di ikuti oleh siswa yang sudah bisa saja tetapi semua siswa berperan dalam pembelajaran. Sesuai dengan penelitian terlebih dahulu oleh Nugroho \& T. Abdul (2013) bahwa "model pembelajaran Kooperatif tipe TGT (Team Games Tournament) mampu meningkatkan motivasi belajar siswa dan dapat meningkatkan rasa kebersamaan siswa".

Sementara itu, modifikasi pembelajaran juga berperan penting pada proses pembelajaran pendidikan jasmani ini. Karena dengan dimodifikasinya pembelajaran akan memudahkan siswa terhadap keterampilan bermain mini voli, dengan begitu tidak ada lagi siswa yang merasa kesakitan dan kesusahan dalam mempertahankan bola di udara. Dari penelitian terdahulu yang di lakukan oleh Aulia. (2015) menyimpulkan bahwa "Pembelajaran mini voli yang di modifikasi dengan media bola karet memberikan pengaruh yang signifikan terhadap peningkatan hasil belajar mini voli”

\section{KESIMPULAN}

Berdasarkan hasil penelitian yang telah dilakukan oleh peneliti, mulai dari observasi awal sampai dengan siklus 2 tindakan 2, peneliti menyimpulkan bahwa penerapan model pembelajaran kooperatif tipe TGT (Team Games Tournamnt) melalui volley ball like games dapat meningkatkan keterampilan bermain mini voli siswa. Sehingga dengan meningkatnya keterampilan bermain mini voli siswa akan berakibat kepada hasil belajar siswa pada aktivitas mini voli juga meningkat, dengan begitu pembelajaran kooperatif tipe TGT (Team Games Tournament) dalam volley ball like games bisa untuk diterapkan pada materi pembelajaran mini voli di sekolah dasar.

\section{DAFTAR PUSTAKA}

Arikunto, S. (2013). Prosedur Penelitian Suatu Pendekatan Praktis. Jakarta: PT Rineka Cipta.

Aulia, Raswin Rahmi (2015). Upaya Peningkatan Hasil Belajar Bola Voli Mini Melalui Pembelajaran Menggunakan Media Bola Karet. Jurnal Ilmu Keolahragaan. 14(1), 68-77

Bahagia, Y. \& Mujianto, S. (2017). Fasilitas dan Perlengkapan Penjas. Bandung: FPOK UPI

Erliana, M. (2014). Pengaruh Pembelajaran Model Bermain Terhadap Keterampilan Passing Bawah Bola Voli Mini. Jurnal Mutlilateral. 13 (1) 53-62

Hasanah, M. \& Rahman, R. (2017). Penerapan Model Pembelajaran Kooperatif Tipe Tgt (Team Game Tournament) Dengan Metode Tutor Sebaya Untuk Menuntaskan Hasil Belajar Siswa. Physisc Education Jurnal. 1(1), 66-82 http://ejournal.unikama.ac.id/index.php/ momentum/index

Karim, D.A, \& Ginanjar A. \& Sugiyanto D. (2017) Pengaruh Model Pembelajaran Team Games Tournament Terhadap Teknis Dasar Passing Bawah Permainan Bola Voli. Jurnal Sains Keolahragaan \& Kesehatan. 2(1) 1-2

Marwati, Sri. (2009). Permainan Bola Voli Mini 
Untuk Anak Sekolah Dasar. Jurnal Pendidikan Jasmani Indonesia. 6(2): 67-95

Murtiyono, Efan \& Raharjo, Herman P. (2015). Meningkatkan Hasil Belajar Bola Voli Mini Melalui Tutor Sebaya Siswa Sekolah Dasar. Journal Of Physical Education Sport, Health and Recreations. 4(7) 1953-1956

Nugroho, D.A., \& T. Abdul, R.S. (2013) Penerapan Model Pembelajaran Kooperatif Tipe TGT (Team Games Tournament) Terhadap Motivasi Siswa Dalam Mengikuti Pembelajaran Bola Voli. Jurnal Pendidikan Olahraga dan Kesehatan, 01(01), 161-165

Nugroho, Wachit. (2012). Aplikasi Model Pembelajaran Kooperatif Tipe Tgt Terhadap Hasil Belajar Bermain Minivoli pada siswa kelas IX SMP Negeri 3 Nguter. Univesitas Sebelas Maret: Surakarta

R. Pudjilah, M. (2017). Meningkatkan Hasil Belajar Bola Voli Melalui Modifikasi Permainan Spoonboot Pada Peserta Didik Kelas V Di SD Negeri Tegal Sari 03 Kecamatan Candisari Kota Semarang. Majalah Ilmiah Pendidikan Dasar 7(1) 95-128 http://Journal.upgris.ac.id/ index.php/malihpeddas

Suherman Adang. (2009). Revitalisasi Pengajaran Dalam Pendidikan Jasmani, Bandung: CV. Bintang WarliArtika

Widiyanti, Esti. (2013). Sikap Siswa Dasar Terhadap Pendidikan Jasmani Olahraga dan kesehatan. Jurnal Pendidikan Olahraga Jasmani Indonesia. 9(2), 73-75 